\title{
Hepatitis $C$ in the criminal justice system: opportunities for global action in the era of viral hepatitis elimination
}

Matthew J. Akiyama

Keywords: HCV, Prison, Jail, Criminal justice system, Correctional setting, Substance use disorders, PWID, HCV elimination, DAA

\section{Background}

In recent years, highly effective, well-tolerated, all oral direct-acting antiviral (DAA) therapies for hepatitis $\mathrm{C}$ virus $(\mathrm{HCV})$ have raised the prospect of an era in which HCV elimination is achievable worldwide. Globally, 71 million individuals are estimated to be living with $\mathrm{HCV}$. In 2016, the World Health Organization (WHO) issued viral hepatitis elimination targets that include diagnosing $90 \%$ of individuals living with $\mathrm{HCV}$, initiating $80 \%$ of those who are eligible on treatment, and reducing incidence by $90 \%$. While the WHO's goals have been made more attainable due to the availability of these new effective therapies, recent modeling data suggest that $80 \%$ of high-income nations are not on track to achieve them by 2030 and nearly $70 \%$ are not expected to meet them before 2050 [1].

Globally, HCV disproportionately affects individuals who intersect with the criminal justice system. Of the estimated 10.2 million people incarcerated worldwide on any given day, approximately $15 \%$, or 1.5 million, are living with HCV [2]. Despite the dramatic epidemiologic disparity between corrections and the community, $\mathrm{HCV}$ is overwhelmingly transmitted outside correctional settings. $\mathrm{HCV}$ is far more common among marginalized populations such as people who use drugs, the homeless, and mentally ill. These groups are overrepresented in correctional settings due to policies related to the

Correspondence: makiyama@montefiore.org

Albert Einstein College of Medicine/Montefiore Medical Center, 3300 Kossuth Ave, Bronx, NY 10467, USA

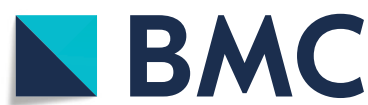

criminalization of drug use and crimes of poverty. High $\mathrm{HCV}$ rates coupled with a point of contact with these marginalized populations make correctional settings critically important to provide all phases of the HCV care cascade (screening, linkage to care, treatment, and prevention).

\section{The HCV care cascade in correctional settings: missed opportunities and priorities for action}

As the first steps in the care cascade, screening and confirmation of chronic HCV infection are important to ensure individuals are aware of their HCV status. Not only is HCV screening in correctional settings complicated by a lack of HCV-related knowledge, incarcerated individuals often do not provide a complete history of injection drug use due to the stigma associated with substance use disorders and fear of incrimination [3]. Therefore, risk-based, targeted screening may miss opportunities to make HCV diagnoses. Universal opt-out HCV testing upon entrance in correctional settings can help mitigate stigma by routinizing testing and raising awareness about HCV infection [4]. In the USA, practice guidelines recommend routine opt-out $\mathrm{HCV}$ screening among all incarcerated individuals [5], yet, the majority are not doing so [6].

For individuals who are diagnosed, linkage to $\mathrm{HCV}$ treatment can be challenging. In general, correctional settings have even less access to DAAs than surrounding communities, particularly in low- and middle-income countries where global access is already poor. Even in 
nations with more widespread access to DAAs like the USA, the majority of facilities do not provide HCV treatment despite comparable outcomes in correctional settings [6, 7]. Moreover, the average length of stay for the one third of individuals residing in short-term US jail facilities is less than two weeks. Therefore, ensuring the completion of an 8- to 12-week course of DAAs is challenging. Similar challenges exist internationally for those on remand. Despite the quick turnover and inability to administer and track the full course of DAAs, shortterm correctional settings serve as an opportunity to continue $\mathrm{HCV}$-care for those already on treatment but also have the potential to engage a large number of individuals unaware of their status into care, and provide testing and education for those at risk for HCV. A study conducted in the New York City jail system found viral load suppression for over $90 \%$ of patients including those who initiated treatment prior to incarceration and those who initiated treatment in the jails, demonstrating the feasibility of DAA access in short-term settings [8].

Upon release, justice-involved individuals face barriers related to social and structural determinants of health such as poor social support and housing, as well as relapse to active substance use. This makes it imperative to connect individuals to community-based social, behavioral, and addiction services prior to their release. One strategy is transitional care coordination, a patient navigation strategy that has proven successful to facilitate linkage to care for patients living with HIV [9]. Implemented on its own or in tandem with existing HIV-focused program, HCV-focused transitional care coordination can also improve linkage to and retention in HCV care [10]. Such programs offer advocacy, health education, and social support to people living with $\mathrm{HCV}$ who are incarcerated and can work with them to create a plan for initiation or continuation of $\mathrm{HCV}$ treatment upon return to the community.

Beyond justice-involved individuals themselves, the high rate of substance use disorders within this population indicates that this group plays a large role in community transmission. Therefore, HCV treatment in correctional settings not only benefits this high-risk population, but paves the way for preventing $\mathrm{HCV}$ transmission in the communities to which justiceinvolved individuals return. Correctional facilities can also provide $\mathrm{HCV}$-related risk-reduction education to prevent new infections, which will not only lead to benefit for HCV, but should also be leveraged to prevent other blood borne and injection-related infections. Linkage to opioid agonist therapy and resources for syringe exchange will also be invaluable to these efforts.

\section{Leveraging correctional settings to support HCV elimination: a call to action}

As HCV continues to disproportionately affect individuals involved with the criminal justice system, the development of effective strategies to promote testing, diagnosis, and linkage to care during incarceration is an opportunity to improve the coordination of care among this high-risk population. Strengthening the HCV-care cascade in correctional settings will move us closer achieving international reduction in new $\mathrm{HCV}$ infections, improving health outcomes for people living with $\mathrm{HCV}$, and reducing $\mathrm{HCV}$-related health disparities. To make $\mathrm{HCV}$ elimination conceivable in the coming decades, we must amplify international political will to tackle $\mathrm{HCV}$ in the criminal justice system; without action among justice-involved individuals, achieving the WHO elimination goals will be difficult to attain.

\section{Acknowledgements}

Not applicable.

\section{Author's contributions}

Dr. Akiyama conceived of and drafted the manuscript. The author read and approved the final manuscript.

\section{Author's information}

Dr. Matthew Akiyama is a clinician-investigator who conducts research on $\mathrm{HCV}$ and HIV among socioeconomically marginalized populations with particular emphasis on the intersection of infectious diseases in the criminal justice system.

\section{Funding}

National Institute of Drug Abuse R00DA043011

Availability of data and materials

Not applicable.

Ethics approval and consent to participate

Not applicable.

Consent for publication

Not applicable.

Competing interests

The author declares no competing interests.

Received: 23 June 2020 Accepted: 24 June 2020

Published online: 14 August 2020

References

1. Razavi H. Global timing of hepatitis C virus elimination: estimating the year countries will achieve the World Health Organization Elimination Targets. AASLD Special Conference on HCV2019.

2. Dolan K, Wirtz AL, Moazen B, Ndeffo-Mbah M, Galvani A, Kinner SA, Courtney R, McKee M, Amon JJ, Maher L, Hellard M, Beyrer C, Altice FL. Global burden of HIV, viral hepatitis, and tuberculosis in prisoners and detainees. Lancet (London, England). 2016;388(10049):1089-102. https://doi. org/10.1016/S0140-6736(16)30466-4 Epub 2016/07/19 PubMed PMID: 27427453.

3. Macalino GE, Dhawan D, Rich JD. A missed opportunity: hepatitis C screening of prisoners. Am J Public Health. 2005;95(10):1739-40. https://doi. org/10.2105/AJPH.2004.056291 Epub 2005/09/28 PubMed PMID: 16186452; PMCID: PMC1449429.

4. Morris MD, Brown B, Allen SA. Universal opt-out screening for hepatitis C virus ( $\mathrm{HCV}$ ) within correctional facilities is an effective intervention to improve public health. Int J Prison Health. 2017;13(3-4):192-9. https://doi. 
org/10.1108/JPH-07-2016-0028 Epub 2017/09/16 PubMed PMID: 28914118; PMCID: PMC5764160.

5. American Association for the Study of Liver Diseases; Infectious Diseases Society of America. HCV Guidance: Recommendations for Testing, Managing, and Treating Hepatitis C 2020 [cited 2020 March 15]. Available from: www.HCVquidelines.org.

6. Beckman AL, Bilinski A, Boyko R, Camp GM, Wall AT, Lim JK, Wang EA, Bruce $\mathrm{RD}$, Gonsalves GS. New hepatitis $C$ drugs are very costly and unavailable to many state prisoners. Health Aff (Millwood). 2016;35(10):1893-901. https:// doi.org/10.1377/hlthaff.2016.0296 Epub 2016/10/06 PubMed PMID: 27702964.

7. Aspinall EJ, Mitchell W, Schofield J, Cairns A, Lamond S, Bramley P, Peters SE, Valerio H, Tomnay J, Goldberg DJ, Mills PR, Barclay ST, Fraser A, Dillon JF, Martin NK, Hickman M, Hutchinson SJ. A matched comparison study of hepatitis $\mathrm{C}$ treatment outcomes in the prison and community setting, and an analysis of the impact of prison release or transfer during therapy. J Viral Hepatitis. 2016;23(12):1009-16. https://doi.org/10.1111/jvh.12580 Epub 2016/ 08/12 PubMed PMID: 27509844; PMCID: PMC5558600.

8. MacDonald R, Akiyama MJ, Kopolow A, Rosner Z, McGahee W, Joseph R, Jaffer $M$, Venters $\mathrm{H}$. Feasibility of treating hepatitis $C$ in a transient jail population. Open Forum Infectious Diseases. 2017;4(3):ofx142. https://doi. org/10.1093/ofid/ofx142 PubMed PMID: 28852680; PMCID: 5569928.

9. Myers JJ, Koester KA, Kang Dufour MS, Jordan AO, Cruzado-Quinone J, Riker A. Patient navigators effectively support HIV-infected individuals returning to the community from jail settings. Int J Prison Health. 2017;13(3-4):213-8. https://doi.org/10.1108/JPPH-08-2016-0037 PubMed PMID: 28914126.

10. Akiyama MJ, Columbus D, MacDonald R, Jordan AO, Schwartz J, Litwin AH, Eckhardt B, Carmody E. Linkage to hepatitis C care after incarceration in jail: a prospective, single arm clinical trial. BMC Infectious Dis. 2019;19(1):703. https://doi.org/10.1186/s12879-019-4344-1 Epub 2019/08/10 PubMed PMID: 31395019; PMCID: PMC6686449.

\section{Publisher's Note}

Springer Nature remains neutral with regard to jurisdictional claims in published maps and institutional affiliations.

Ready to submit your research? Choose BMC and benefit from:

- fast, convenient online submission

- thorough peer review by experienced researchers in your field

- rapid publication on acceptance

- support for research data, including large and complex data types

- gold Open Access which fosters wider collaboration and increased citations

- maximum visibility for your research: over $100 \mathrm{M}$ website views per year

At $\mathrm{BMC}$, research is always in progress.

Learn more biomedcentral.com/submissions 